\title{
KERAGAAN PRAKTIK KEARIFAN LOKAL DAN KEBERLANJUTAN HUTAN NAGARI
}

\section{Variety of Local Wisdom Practies in The Management of Nagari's Forest and It's Effect on Resource Sustainability}

\author{
Aditya Muhammad ${ }^{1)}$ dan Saharuddin ${ }^{1)}$ \\ ${ }^{1)}$ Departemen Sains Komunikasi dan Pengembangan Masyarakat, Fakultas Ekologi Manusia, \\ Institut Pertanian Bogor, Darmaga Bogor 16680, Indonesia \\ E-mail: bangadit17@gmail.com; saharuddin@apps.ipb.ac.id
}

\begin{abstract}
Local wisdom is very influential in forest conservation, for indigenous forest communities to have sustainable functions either from the environmental or ecological, economic and socio-cultural fields. The objectives of this study were to: (1) analyze the nagari forest management practices, (2) Analyze the values and practices of local wisdom on the management of nagari forests, (3) analyze the sustainability of nagari forests, (4) to analyze the relation of nagari forest management practices to the sustainability of forests nagari. Research methods used to explore facts, data, and information in this study used a quantitative approach with a questionnaire supported by in-depth interviews and observation. The results of this study indicate that there is an unidirectional relationship between the indicators of the characteristics of the nagari forest and the sustainability of the nagari forest consisting of ecological, socio-cultural and economic sustainability. On the other hand, the management practices of nagari forests are linked to the sustainability of nagari forests but not significant.
\end{abstract}

Keywords : Forest sustainability, Local wisdom

\section{ABSTRAK}

Kearifan lokal sangat berpengaruh didalam pelestarian hutan, bagi masyarakat adat hutan memiliki fungsi yang berkelanjutan baik itu dari bidang lingkungan atau ekologi, ekonomi dan sosial-budaya. Tujuan dari penelitian ini adalah untuk: (1) menganalisis praktik pengelolaan hutan nagari, (2) Menganalisis nilai dan praktik kearifan lokal pada pengelolaan hutan nagari, (3) menganalisis keberlanjutan hutan nagari, (4) menganalisis hubungan praktik pengelolaan hutan nagari dengan keberlanjutan hutan nagari. Metode penelitian yang digunakan untuk menggali fakta, data, dan informasi dalam penelitian ini digunakan pendekatan kuantitatif dengan kuesioner yang didukung dengan wawancara mendalam dan observasi. Hasil penelitian ini menunjukkan bahwa terdapat hubungan yang tidak searah antara indikatorindikator karakteristik hutan nagari dengan keberlanjutan hutan nagari yang terdiri dari keberlanjutan ekologi, sosialbudaya dan ekonomi. Di sisi lain, praktik pengelolaan hutan nagari memiliki hubungan dengan keberlanjutan hutan nagari namun tidak signifikan.

Kata Kunci : Kearifan lokal, Keberlanjutan hutan

\section{PENDAHULUAN}

Provinsi Sumatera Barat memiliki kearifan lokal dalam mengelola sumber daya hutan, sebagai salah satu provinsi yang dikenal bijak dalam mengelola kelestarian alam dan merupakan provinsi yang masih memiliki hutan yang terjaga kealamiannya. Kearifan lokal sangat berpengaruh didalam pelestarian hutan, bagi masyarakat adat hutan memiliki fungsi yang berkelanjutan baik itu dari bidang ekonomi bahkan sampai kepada bidang sosial dan budaya. Masyarakat adat Minangkabau sendiri memiliki filosofi yang menyatakan bahwa apa yang ada di alam merupakan guru bagi masyarakat atau lebih dikenal dengan istilah "Alam Takambang Jadi Guru", filososfi ini menyatakan bahwa alam harus dijaga dan dirawat keasriannya karena dapat memberikan suatu pelajaran yang bermakna bagi masyarakat dan bermanfaat bagi lingkungan Idris (2012). Keterkaitan antara masyarakat dengan hutan 
telah berlangsung cukup lama karena hutan telah memberikan manfaat bagi masyarakat secara ekonomi, sosial, budaya ataupun keberlanjutan ekologi.

Pengelolaan hutan berdasarkan kearifan lokal di Sumatera Barat, dinilai mampu oleh pemerintah untuk menjadikan Sumatera Barat sebagai salah satu contoh model pengelolaan hutan adat terpadu. Pengelolaan hutan ini dapat mewujudkan program pemerintah dalam menanggulangi perubahan iklim secara global. Program pengurangan emisi karbon ini dikenal dengan istilah $\mathrm{REDD}+$, program ini dapat berjalan jika adanya dukungan dari pemerintah daerah dan masyarakat lokal. Hutan nagari yang sudah terkenal baik dan dinilai sudah mendukung program REDD+ tersebut adalah hutan nagari Sungai Buluh dan Hutan Nagari Paru luas wilayah hutan tersebut mencakup setengah luas daerah tempat tinggal masyarakat.

Sejak dikeluarkannya surat edaran pengelolaan kawasan hutan nagari di Sumatera Barat masyarakat lokal berlomba-lomba untuk mengelola kawasan hutan adat sebagai kawasan yang sangat memiliki nilai jual tinggi salah satunya adalah sebagai daya tarik untuk penelitian oleh ilmuwan atau sebagai tempat berwisata alternatif bagi masyarakat (Ekowisata) dengan adanya pengelolaan secara mandiri ini diharapkan masyarakat sekitar dapat terkena dampak dari pengelolaan hutan nagari baik itu dari segi ekonomi, ekologi maupun kesejahteraan sosial. Keberadaan hutan juga memberikan kesempatan bagi masyarakat untuk bekerja terutama dalam hal pembukaan lahan, penebangan kayu, sehingga memperoleh upah yang lumayan. Selain itu bagi masyarakat yang hidupnya bergantung pada sumber-sumber dasar yang terdapat di hutan seperti kayu bakar, dan hasil hutan lainnya akan memberikan nilai tambah terutama bagi masyarakat yang berada disekitar kawasan hutan Karisma (2010).

Hutan di Sumatera Barat dikelola dengan sistem ulayat atau kaum, hak ulayat ini hanya dimiliki oleh kesatuan-kesatuan masyarakat dan tidak boleh dimiliki oleh orang lain selain masyarakat yang ada dikaum tersebut. Pengertian "ulayat" di
Minangkabau lebih kuat ke arah pengertian sebagai tanah milik komunal seluruh suku Minangkabau. Tanah ulayat adalah pusaka yang diwariskan turun-temurun, yang haknya berada pada perempuan, namun sebagai pemegang hak atas tanah ulayat adalah mamak kepala waris. Penguasaan dan pengelolaan tanah ulayat dimaksudkan untuk melindungi dan mempertahankan kehidupan serta keberadaan masyarakat (eksistensi kultural). Selain itu, tanah ulayat juga mengandung unsur religi, kesejarahan dan bahkan unsur magis serta bertujuan memakmurkan rakyat di dalamnya Iswantoro (2012).

Adanya pengelolaan hak ulayat dalam pengelolaan tanah di Minangkabau menjadi salah satu faktor yang menghambat proses pembangunan di Sumatera Barat menjadikan kalangan investor susah untuk masuk kewilayah tanah yang menjadi milik kaum di suatu nagari kecuali melalui beberapa tahapan seperti serah terima hak tanah yang dilakukan oleh para ninik mamak kepada bupati atau kepala daerah dengan kesepakatan ganti rugi yang sesuai dengan sistem bagi hasil hak usaha, apabila tanah ulayat nagari dijual maka hubungan masyarakat dengan pihak luar tetap terjalin dalam ikatan kontrak Warman (2014) dengan adanya pengelolaan tatanan kepemilikan tanah yang rumit dan menjadi satu sebagai satu kesatuan yang tertuang dalam sistem kehidupan sosial di Minangkabau.

Kearifan lokal masyarakat Minangkabau tentu saja tidak akan berjalan dengan suatu pemerintahan yang tidak jelas, pada sistem pemerintahan di Minangkabau dikenal juga dengan sistem pemerintahan nagari. Bentuk pemerintahan nagari sendiri merupakan bentuk nyata dari terwujudnya desentralisasi pemerintahan pusat kepada daerah berdasarkan UU No.22 Tahun 1999 tentang Pemerintahan Daerah. UU ini menyatakan berakhirnya kekuasaan sentralistik dan mulai dipakainya sistem otonomi daerah di Indonesia. Otonomi daerah adalah kewenangan daerah otonom untuk mengatur dan mengurus kepentingan masyarakat setempat menurut prakarsa sendiri 
berdasarkan aspirasi masyarakat menurut peraturaan perundang-undangan. Semenjak berlaku UU tersebut pemerintah Sumatera Barat dapat mengelola sistem pemerintahan sendiri dengan kearifan lokal yang berlaku disetiap daerah baik itu di tingkat kabupaten/kota.

Pengelolaan hutan berdasarkan kearifan lokal di Sumatera Barat tidak saja mengenai tata cara pengelolaan hutan secara tradisional hal ini bisa memberikan dampak kepada perekonomian masyarakat. Adanya penetapan kawasan hutan antara hutan produksi/olahan/parak, hutan simpanan dan rimbo larangan tidak akan menutup kemungkinan bagi masyarakat sekitar hutan untuk dapat mengakses sumber daya yang ada di hutan tersebut.

Tanpa disadari berbagai tindakan dan sikap manusia telah mengarah kepada eksploitasi alam secara berlebihan, penggunaan teknologi yang tidak tepat guna atau berlebihan salah satu contoh yang dapat mengganggu keseimbangan alam seperti perubahan iklim, krisis air bersih, pencemaran udara, dan berbagai krisis ekologi jika kejadian ini terus diabaikan maka akan berdampak juga kepada perekonomian masyarakat yang berada disekitar hutan. Oleh sebab itu perlu pengembangan dan pelestarian kearifan lokal yang sudah ada dimasyarakat, agar kelestarian hutan tetap terjaga dan roda perekonomian masyarakat yang berada dikawasan hutan juga terus berjalan. Berdasarkan hal tersebut, muncul ketertarikan bagi peneliti untuk menganalisis lebih mendalam mengenai bagaimana peran praktik pengelolaan hutan nagari dalam keberlanjutan hutan nagari?

Hutan memiliki fungsi sosial, ekonomi dan ekologis. Manfaat hutan bagi masyarakat adalah untuk pemenuhan kebutuhan hidup dan menjadi salah satu sumber mata pencaharian. Indonesia memiliki beberapa model pengelolaan hutan. Pengelolaan hutan yang baik adalah pengelolaan yang melibatkan masyarakat disekitar hutan (partisipatif). Pengelolaan hutan yang partisipatif akan terwujud jika didasarkan pada kearifan lokal masyarakat yang berlaku dikawasan sekitar hutan tersebut. Kearifan lokal sangat penting bagi pelestarian hutan yang ada di Indonesia, maka perlu dikaji lebih dalam lagi bentuk-bentuk kearifan lokal untuk mewujudkan pelestarian hutan. Masyarakat yang berada di sekitar hutan dalam mengelola sumberdaya hutan sangat tergantung pada pengetahuan dan kemampuan dalam pengelolaan dan pemanfaatan sumberdaya. Berdasarkan penjelasan tersebut bagaimana hutan nagari dikelola dengan menggunakan nilai-nilai kearifan masyarakat setempat?

Secara normatif, tujuan utama pengelolaan hutan sebenarnya adalah memanfaatkan seoptimal mungkin fungsi hutan. Secara konseptual sumber daya hutan memiliki 3 fungsi utama yang saling terkait satu sama lain, yakni fungsi ekonomi, fungsi ekologi, dan fungsi sosial budaya. Sumber daya hutan secara ekonomi diharapkan bisa menjadi sumber peningkatan kesejahteraan masyarakat. Secara ekologis sumber daya hutan diharapkan bisa menjadi salah satu faktor utama terwujudnya keberlanjutan ekosistem secara lintas generasi. Sedangkan secara sosial budaya sumber daya hutan diharapkan bisa menjadi sumber kehidupan masyarakat melalui sistem dan praktik pengelolaan hutan.

Ketiga fungsi pokok sumber daya hutan haruslah dimanfaatkan secara adil dan demokratis dengan menjunjung tinggi aspek kelestarian dan keberlanjutannya sehingga dapat dinikmati oleh anak cucu penerus bangsa Murtijo (2005). Berdasarkan tujuan dan fungsi pengelolaan hutan tersebut, bagaimana praktik nilai-nilai kearifan setempat memperkuat aspek-aspek keberlanjutan hutan nagari?

Kearifan lokal yang diterapkan dalam pengelolaan hutan-hutan di Indonesia tidak saja berdampak kepada pelestarian lingkungan sekitar. Salah satu faktor keberhasilan pengelolaan hutan adalah adanya kearifan masyarakat yang masih berlaku dan terus diwariskan kepada generasi berikutnya, berdasarkan hal tersebut penting untuk dianalisis bagaimana peran praktik kearifan setempat membentuk keberlanjutan hutan nagari?

\section{PENDEKATAN TEORITIS}

\section{Konsep Kearifan Lokal}

Kearifan lokal yang berkembang dimasyarakat merupakan strategi adaptasi yang muncul dengan 
kesadaran mayarakat sendiri. Kearifan lokal juga berfungsi sebagai ruang untuk pemecahan masalah sosial yang terjadi di masyarakat. Pengertian kearifan lokal, menurut Keraf (2002) seperti dikutip oleh Arafah (2011) adalah semua bentuk pengetahuan, keyakinan, pemahaman atau wawasan serta adat kebiasaan atau etika yang menuntun perilaku manusia dalam kehidupan di dalam komunitas ekologis.

Kearifan lokal yang digunakan oleh masyarakat Minangkabau pada praktik pengelolaan hutan diatur dalam bentuk peraturan-peraturan yang berlaku dimasyarakat. Peraturan tersebut tertuang didalam petatah-petitih adalah patokan hukum adat yang menjadi sumber dari peraturan yang mengatur segala hubungan dalam masyarakat Minangkabau. Pepatah dapat disimpulkan sebagai hukum dasar atau pedoman utama dalam masyarakat Minangkabau. Petitih adalah aturan yang mengatur pelaksanaan adat dengan seksama. Petitih merupakan peraturan operasional, pelaksanaan dan batasan peraturan di dalam masyarakat. Jadi, petatah adalah pedoman hukum adat, sedangkan petitih berfungsi sebagai peraturan pelaksana Rahayu et al. (2013).

Kearifan lokal adat Minangkabau dapat diamati pelaksanaannya dari aturan-aturan dan norma-norma yang masih berlaku di daerah tersebut. Penerapan nilai-nilai adat dan kearifan lokal, diberlakukan oleh penghulu terhadap masyarakatnya adalah untuk melestarikan hutan ataupun sumber daya alam yang dapat dimanfaatkan oleh masyarakat.

\section{Hutan dan Hutan Adat}

Hutan merupakan suatu sumberdaya alam tinggi yang mempunyai nilai ekonomi yang sangat tinggi, nilai ekonomi yang tinggi tersebut terdapat pada bagian yang sangat vital dari pabrik hutan, yaitu pohon-pohon sebagai pabrik kayu. Hal ini di dukung oleh pendapat Yamani (2011) bahwa hutan pun mempunyai 3 fungsi yaitu: fungsi ekonomi sebagai sumber kehidupan baik langsung maupun tidak langsung, kedua fungsi ekologi yaitu sebagai cadangan air, dan terakhir adalah fungsi sosial budaya yaitu hutan menyediakan kebutuhan upacara adat, tempat sara melakukan pertemuan rahasia untuk membicarakan berbagai hal tentang kondisi masyarakat. Hal ini dapat dilihat pada masyarakat Baduy menurut Senoaji (2010) dalam masyarakat Baduy mereka percaya bahwa mereka diciptakan untuk mengelola tanah suci yang menjadi pusat bumi. Tanah Baduy dilarang rusak, gunung tidak boleh dilebur, hutan tidak boleh dirusak, aliran air tidak boleh diganggu dan lembah tidak boleh dirusak.

Menurut Putusan Mahkamah Konstitusi Nomor 35/PUU-X/2012, menegaskan bahwa: "Hutan adat adalah hutan negara yang berada dalam wilayah masyarakat hukum adat". Kata "negara" dihapuskan oleh MK sehingga bunyi Pasal 1 angka 6 menjadi sebagai berikut: "Hutan adat adalah hutan yang berada dalam wilayah masyarakat hukum adat". Hutan adat adalah kawasan hutan yang berada di dalam wilayah adat yang merupakan bagian yang tidak terpisahkan dari siklus kehidupan komunitas adat penghuninya. Pada umumnya komunitaskomunitas masyarakat adat penghuni hutan di Indonesia memandang bahwa manusia adalah bagian dari alam yang harus saling memelihara dan menjaga keseimbangan dan harmoni. Hutan adat dapat dibuktikan dengan verifikasi hukum adat dan korelasi eksistensi hutan dengan budaya komunitas pemangkunya.

\section{Pengelolaan Hutan Adat}

Penetapan hutan adat berdasarkan Peraturan Daerah (Perda) tentang pengakuan terhadap masyarakat adat, disamping itu juga harus mempunyai wilayah adat yang telah tertuang dalam peta partisipatif yang diakui oleh batas spadan. Agar pengakuan terhadap masyarakat bisa didorong dalam perda sesuai dengan mandat pasal 67 ayat 2 UU No.41 Tahun 1999 maka harus memenuhi unsur-unsur yaitu sejarah (masyarakatnya masih paguyuban), ada kelembagaan adat, hukum adat, wilayah adat serta masyarakatnya masih melakukan pemungutan hasil hutan.

Menurut Karten (1986) seperti dikutip oleh Arafah et all. (2011) pengelolaan sumberdaya alam berbasis masyarakat dilakukan dengan tiga alasan yaitu :

1. Local variety: masyarakat lokal punya karakteristik lingkungan yang beragam baik dalam aspek biofisik, sosial dan ekonomi harus ditanggapi secara tepat dan cepat.

2. Local resources: sumberdaya berada ditengah-tengah masyarakat yang dibutuhkan dan saling ketergantungan.

3. Local accountability: masyarakat yang mempunyai ketergantungan terhadap sumberdaya akan memiliki komitmen dan tanggung jawab penuh untuk mengelola sumberdaya secara bijaksana sesuai prinsip kearifan lokal. 
Menurut Firmasyah (2016) secara umum konsepsi pengelolaan hutan di Sumatera Barat adalah konsepsi komunalistik yang didasarkan pada penguasaan ulayat atas sumberdaya alam. Konsepsi ulayat sendiri merupakan penguasaan sumber daya alam secara komunal dari susunan masyarakat yang kolektif. Konsepsi ulayat bersifat holistik, baik itu pada ruang tanah, hutan, air, danau, dan laut. Sesuai dengan pepatah Minangkabau: $k a$ rimbo babungo kayu (ke rimba berbunga kayu); ka ladang babungo ampiang (ke ladang berbunga emping); ka sungai babungo pasie (ke sungai berbunga pasir); ka lauik babungo karang (ke laut berbunga karang). Sehingga penguasaan masyarakat adat nagari atas hutan merupakan bagian dari penguasaan mereka atas ulayat. Hutan dipandang sebagai pengikat dan penanda kolektivisme serta media untuk terus mempertahankan ikatan kekerabatan. Karenanya bagi masyarakat Nagari hutan yang merupakan bagian dari ulayat tidak diposisikan sekedar faktor produksi belaka, tetapi juga sebagai pengikat hubungan sosial masyarakat. Penguasaan kolektif tersebutlah membentuk ikatan kekerabatan dalam penguasaan ulayat, yang dibagi atas tingkatan kekerabatan matrilineal mulai dari paruik (perut), kaum, suku dan nagari. Karena itu adat nagari melarang terjadinya perpindahan dan pelepasan hakhak ulayat.

Menurut Firmansyah (2007) berdasarkan pengaturan tersebut, hutan dibagi menjadi tiga peruntukkan kawasan, yaitu: (1) rimbo larangan/rimbo larangan sebagai zero growth, (2) hutan simpanan sebagai hutan cadangan yang diperuntukkan bagi anak kemenakan generasi berikutnya, dan (3) hutan parak sebagai kawasan hutan yang dikelola, yang umumnya dengan sistem parak (ladang). Untuk membuat peraturan-peraturan tersebut masyarakat di Minangkabau memiliki sistem pemerintahan nagari yang berwenang dalam menetapkan peraturanperaturan adat.

\section{Perilaku Masyarakat Sekitar Hutan}

Hutan bagi masyarakat bukanlah hal yang baru, terutama bagi masyarakat yang masih memiliki nilainilai dan kultur tradisional. Sejak jaman dahulu, mereka tidak hanya melihat hutan sebagai sumber daya potensial saja, melainkan memang merupakan sumber pangan, obat-obatan, energi, sandang, lingkungan dan sekaligus tempat tinggal mereka. Bahkan sebagian masyarakat tradisional yang meyakini bahwa hutan memiliki nilai spiritual, yakni dimana hutan atau komponen biotik dan abiotik yang ada di dalamnya sebagai obyek yang memiliki kekuatan atau pesan supranatural yang mereka patuhi Fauzi (2012).

Masyarakat lokal adalah elemen penting dalam pengelolaan hutan lestari. Adanya kearifan lokal dan nilai-nilai budaya yang dimiliki oleh masyarakat telah menjadikan mereka sebagai konservasionis sejati. Pola pemanfaatan lahan dan sumber daya hutan yang ideal harus mampu didukung oleh kesadaran untuk menjaga, serta mengoptimalkan setiap elemen yang terlibat di dalamnya. Aktifitas pertanian dan perkebunan yang dilakukan disisi lain memberikan tingkat kerawanan terhadap kerusakan hutan, sebab area kebun warga sekitar hutan dapat menjangkau wilayah hutan. Desakan kebutuhan hidup membuat warga sekitar hutan memanfaatkan lahan dan hasil hutan sebagai bagian dari pemenuhan hidup. Hutan memiliki fungsi ganda khususnya bagi masyarakat yang tinggal di sekitar hutan karena mereka terlibat langsung dengan hutan tersebut.

\section{Ancaman Terhadap Kelestarian Hutan}

Menurut Suyanto (2009) ada beberapa faktor yang menjadi ancaman bagi kelestarian hutan diantaranya pertumbuhan penduduk yang cepat, perkembangan ilmu pengetahuan dan teknologi. Adanya semangat otonomi daerah dewasa ini, mengakibatkan semakin meningkatknya aktivitas esploitasi terhadap sumberdaya alam baik yang terdapat dalam kawasan budidaya maupun kawasan hutan produksi, bahkan dalam kawasan hutan lindung sekalipun yang seharusnya dijaga dan dilestarikan untuk tujuan perlindungan tidak luput dari incaran kegiatan eksploitasi. Fakta menunjukkan bahwa kawasankawasan tersebut kini telah mengalami kerusakan yang cukup parah karena mendapat tekanan dari berbagai pihak.

Gejala tersebut dapat dirasakan banyaknya indikasi berbagai bencana alam seperti: banjir, kekeringan, tanah longsor, kebakaran lahan / hutan, pencemaran lingkungan dan perubahan iklim global. Ancaman terhadap kawasan hutan lindung akhir - akhir ini semakin meningkat, terutama setelah potensi tegakan dalam kawasan hutan produksi semakin habis.

\section{Pembangunan Berkelanjutan}

Istilah berkelanjutan pertama kali dikenalkan pada tahun 1987 oleh World Comission on Environment and Development (Brundtland Comission) melalui 
bukunya Our Common Future. Menurut Munasingle (1993) seperti dikutip oleh Ruchyat (2003) menyatakan bahwa pembangunan berkelanjutan pada dasarnya mencakup tiga dimensi penting, yakni ekonomi, sosial dan ekologi. Dengan demikian, tujuan pembangunan berkelanjutan terfokus pada keberlanjutan laju pertumbuhan ekonomi yang tinggi (economic growth), keberlanjutan kesejahteraan sosial yang adil dan merata (sosial progress), serta keberlanjutan ekologi dalam tata kehidupan yang serasi dan seimbang (ecological balance).

Pembangunan berkelanjutan merupakan aktivitas memanfaatkan seluruh sumberdaya, guna meningkatkan kualitas hidup dan kesejahteraan masyarakat. Pelaksanaan pembangunan pada dasarnya juga merupakan upaya memelihara keseimbangan antara lingkungan alami (sumberdaya alam hayati dan non hayati) dan lingkungan binaan (sumberdaya manusia dan buatan), sehingga sifat interaksi maupun interdepensi antar keduanya tetap dalam keserasian yang seimbang. Menurut Abdurrahman (2003) pengaturan mengenai pemanfaatan sumberdaya alam telah diatur dalam Undang - undang No. 23 Tahun 1997 pengaturan tentang pengelolaan sumber daya alam dimaksud diatur dalam Bab IV tentang wewenang pengelolaan lingkungan hidup. Secara umum dalam pasal 1 angka 10 disebutkan bahwa sumber daya adalah unsur lingkungan hidup yang terdiri atas sumber daya manusia, sumber daya alam baik hayati maupun non hayati dan sumber daya buatan.

Kemudian dalam pasal 9 ayat (3) pengelolaan lingkungan hidup wajib dilakukan secara terpadu dengan penataan ruang, perlindungan sumber daya alam non hayati, perlindungan sumber daya buatan, konsensus sumber daya alam hayati dan eksistensinya, cagar budaya, keanekaragaman hayati dan perubahan iklim. Pengaturan tentang pengelolaan sumber daya alam yang dikaitkan dengan pembangunan yang berkelanjutan tampak dengan jelas dalam Undang - Undang No. 41 Tahun 1999 Tentang Kehutanan. Pasal 3 dari UndangUndang ini misalnya menentukan: "Penyelenggaraan kehutanan bertujuan untuk sebesar-besarnya kemakmuran rakyat yang berkeadilan dan berkelanjutan.

Selanjutnya dapat disebutkan ada dua ketetapan MPR yang membicarakan pengelolaan sumber daya alam yang di bukukan sejalan dengan prinsip pembangunan yang berkelanjutan, pertama adalah Tap MPR No. IV/MPR/1999 tetang Garis-garis
Besar Haluan Negara 1999-2004, walau arah kebijakan-kebijakan pembangunan bidang sumber daya alam dan lingkungan hidup disebut:

1. Mengelola sumber daya alam dan memelihara daya dukungnya agar bermanfaat bagi peningkatan kesejahteraan rakyat dari generasi.

2. Meningkatkan pemanfaatan potensi sumber daya alam dan lingkungan hidup dengan melakukan konservasi, rehabilitasi dan penghematan penggunaan dengan menerapkan teknologi ramah lingkungan.

3. Mendelegasikan secara bertahap wewenang pemerintah pusat kepada pemerintah daerah dalam pelaksanaan pengelolaan sumber daya alam secara selektif dan pemeliharaan lingkungan hidup sehingga kualitas ekosistem tetap terjaga yang diatur dengan UndangUndang.

4. Mendayagunakan sumber daya alam untuk sebesar-besarnya kemakmuran rakyat dengan memperhatikan kelestarian fungsi dan keseimbangan lingkungan hidup, pembangunan yang berkelanjutan, kepentingan ekonomi dan budaya masyarakat lokal, serta penataan ruang yang pengusahaanya diatur dengan UndangUndang.

5. Menerapkan indikator-indikator yang memungkinkan pelestarian kemampuan, keterbatasan sumber daya alam yang dapat diperbaharui untuk mencegah kerusakan yang tidak dapat balik. Lima prinsip ini kemudian dijabarkan lebih jauh dalam UU No. 25 Tahun 2000 tentang program pembangunan nasional (Propenas).

\section{Keberlanjutan Ekologi, Sosial Budaya dan Ekonomi}

Secara normatif, tujuan utama pengelolaan hutan sebenarnya adalah memanfaatkan seoptimal mungkin fungsi hutan. Secara konseptual sumber daya hutan memiliki 3 fungsi utama yang saling terkait satu dengan yang lain, yakni fungsi ekonomi, fungsi ekologi, dan fungsi sosial budaya. Sumber daya hutan secara ekonomi diharapkan bisa menjadi sumber peningkatan kesejahteraan masyarakat. Secara ekologis sumber daya hutan diharapkan bisa menjadi salah satu faktor utama terwujudnya keberlanjutan ekosistem secara lintas generasi. Sedangkan secara sosial budaya sumber daya hutan 
diharapkan bisa menjadi sumber kehidupan masyarakat melalui system dan praktik pengelolaan hutan. Ketiga fungsi pokok sumber daya hutan haruslah dimanfaatkan secara adil dan demokratis dengan menjunjung tinggi aspek kelestarian dan keberlanjutannya sehingga dapat dinikmati oleh anak cucu penerus bangsa Murtijo (2005).

\section{Keberlanjutan Ekologi}

Pembangunan berkelanjutan berbasis ekologi adalah untuk menciptakan sistim yang berkelanjutan berbasis lingkungan maka kita harus mampu memelihara sumberdaya agar tetap dalam keadaan stabil, menghindari terjadinya eksploitasi alam agar tumbuhan dapat melakukan fungsi penyerapan secara sempurna.

2. Keberlanjutan Sosial-Budaya

Konsep pembangunan sosial merupakan suatu model alternatif yang ditawarkan karena model pembangunan yang lebih mementingkan pertumbuhan ekonomi tidak juga dapat meningkatkan kesejahteraan.

\section{Keberlanjutan Ekonomi}

Pengelolaan kawasan hutan adat harus benarbenar dilakukan dengan penuh kehati-hatian dan pengelolaan yang cermat, tidak terjebak atau tergiur pada keuntungan ekonomi jangka pendek, tetapi harus berpedoman pada pengembangan berkelanjutan. Sebuah pembangunan ekonomi lokal memiliki keuntungan-keuntungan ekonomi untuk masyarakat secara keseluruhan dan tidak mengandung ancaman terhadap modal alami dan buatan. Ekonomi yang adil secara sosial atau berhubungan dengan kerangka ekologi adalah ekonomi yang berkelanjutan. Untuk mencapai kemandirian ekonomi lokal, berbagai kasus dilakukan terhadap kegiatan ekonomi.

Pengembangan Ekonomi Lokal sebagai proses yang dilakukan secara bersama oleh pemerintah, usahawan, dan organisasi non pemerintah untuk menciptakan kondisi yang lebih baik untuk pertumbuhan ekonomi dan penciptaan lapangan kerja di tingkat lokal. Pengelolaan kawasan hutan adat secara mandiri tidak saja memperoleh keuntungan secara ekologinamun keuntungan ekonomi juga dapat dirasakan oleh masyarakat. Peningkatan perekonomian pada kawasan hutan menurut Kristiani (2002) seperti dikuti oleh Astrid
(1997) dapat dilihat dari bentuk rumah, pekerjaan dan profesi. Taraf hidup dapat dilihat melalui Kebutuhan Hidup Layak (KHL) adalah standar kebutuhan seorang pekerja untuk dapat hidup layak secara fisik dalam 1 bulan.

\section{Kerangka Pemikiran}

Kearifan lokal terbentuk karena adanya interaksi masyarakat dengan lingkungan sehingga dengan adanya kearifan lokal dapat membantu masyarakat untuk menjadi masyarakat yang mandiri. Menurut Nababan (2008) seperti dikutip oleh Mulyadi (2013) kearifan lokal terbentuk karena adanya hubungan antara masyarakat tradisional dengan ekosistem disekitarnya, yang memiliki kepercayaan, hukum dan pranata adat, pengetahuan dan cara mengelola sumberdaya alam secara lokal.

\begin{tabular}{|l|l|}
\hline \multicolumn{1}{|c|}{ Praktik } \\
Pengelolaan Hutan \\
1.Rimbo Larangan \\
2.Hutan Simpanan \\
3.Hutan \\
Olahan/Parak
\end{tabular}$-$\begin{tabular}{l}
\multicolumn{1}{|c|}{ Keberlanjutan } \\
Hutan Nagari \\
1.Keberlanjutan \\
Ekologi \\
2.Keberlanjutan \\
Sosbud \\
3.Keberlanjutan \\
Ekonomi
\end{tabular}

Gambar 1. Kerangka berpikir Keragaan Praktik Kearifan Lokal dan Keberlanjutan Hutan Nagari

Menurut Firmansyah (2007) terdapat 3 bentuk praktik kearifan lokal dalam pengelolaan hutan di Minangkabau yaitu: (1) Rimbo larangan, (2) Hutan simpanan, (3) Hutan olahan atau Parak. Marwa et al. (2010) mengemukakan bahwa pengelolaan hutan yang baik harus dapat memberikan manfaat yang optimal bagimasyarakat dengan memperhatikan aspek ekologi, sosial ekonomi dan budaya masyarakat sekitar hutan. Situasi dan kondisi sosial budaya, lingkungan dan ekonomi masyarakat sekitar merupakan aspek yang sangat penting untuk diperhatikan dalam pengelolaan hutan. Dalam pengelolaan hutan berdasarkan kearifan lokal perlu diperhatikan dampak pengelolaan hutan terhadap sosial ekonomi masyarakat di sekitar kawasan hutan. Dari pendapat di atas dapat diketahui bahwa status sosial ekonomi adalah kemampuan seseorang untuk mampu menempatkan diri dalam lingkungannya sehingga dapat menentukan sikap berdasarkan atas apa yang dimilikinya dan kemampuan mengenai 
keberhasilan menjalankan usaha dan berhasil mencukupi kebutuhan hidupnya.

\section{METODE PENELITIAN}

Penelitian ini menggunakan pendekatan penelitian kuantitatif dengan metode survei dan dikuatkan data kualitatif. Penelitian kuantitatif dilakukan dengan menggunakan survei melalui instrumen kuesioner yang diberikan kepada responden. Pendekatan kuantitatif untuk menjawab pertanyaan kearifan lokal dalam pengelolaan hutan dan dampak pengelolaan terhadap kondisi ekologi, sosial budaya dan ekonomi masyarakat. Penelitian ini juga bersifat ekplanatori karena menjelaskan hubungan antar variabel melalui pengujian hipotesa Singarimbun dan Effendi (1989).

Sementara itu data kualitatif untuk mendukung penelitian kuantitatif. Pendekatan penelitian kualitatif dilakukan dengan menggunakan wawancara mendalam kepada informan menggunakan panduan pertanyaandan akan dipaparkan dalam bentuk catatan harian lapang. Informasi yang diperoleh melalui pendekatan kualitatif ini digunakan untuk mendukung dan sebagai interpretasi terhadap data yang didapatkan dari pendekatan kuantitatif mengenai kondisi ekologi, sosial budaya dan ekonomi masyarakat dalam pengelolaan hutan.

Lokasi yang dipilih dalam penelitian ini adalah Nagari Sungai Buluh, kecamatan Batang Anai, Kabupaten Padang Pariaman, dan Nagari Paru, kecamatan Sijunjung, Kabupaten Sijunjung Provinsi Sumatera Barat. Lokasi tersebut dipilih secara purposive dengan pertimbangan lokasi tersebut telah memenuhi beberapa kriteria yang dibutuhkan dalam penelitian ini. Kriteria dalam pemilihan lokasi tersebut, antara lain:

1. Kriteria pertama, adanya kearifan lokal dimasyarakat yang khas dalam mengelola kawasan hutan adat.

2. Kriteria kedua, berkaitan dengan tujuan penelitian yang ingin melihat dampak kearifan lokal dalam pengelolaan hutan terhadap keberlanjutan ekologi, sosial budaya dan ekonomi masyarakat karena pengelolaan hutan yang dikolaborasikan dengan kearifan lokal akan memiliki dampak terhadap keberlanjutan ekologi, sosial budaya dan perekonomian masyarakat disekitar hutan.

Data yang digunakan dalam penelitian ini terdiri dari data primer dan data sekunder. Data primer diperoleh langsung di lapangan dengan cara survey, observasi dan wawancara mendalam baik dengan menggunakan instrumen kuesioner yang ditanyakan kepada responden maupun panduan wawancara yang ditanyakan kepada informan. Sementara itu, data sekunder diperoleh dari dokumen dan berbagai literatur yang relevan dengan penelitian ini, yaitu buku, jurnal penelitian, dan internet.

Sumber data dalam penelitian ini adalah informan dan responden. Informan adalah orang yang termasuk dalam kegiatan ini yang memberikan informasi atau keterangan penelitian. Sedangkan responden merupakan sumber data utama yang diberikan kuesioner. Responden merupakan individu yang dapat memberikan keterangan atau informasi mengenai dirinya sendiri berkaitan dengan penelitian yang dilakukan. Populasi dari penelitian ini adalah rumah tangga masyarakat lokal nagari Sungai Buluh dan Nagari Paru. Pemilihan responden dilakukan dengan menggunakan teknik simple random sampling. Pengumpulan data diperoleh dari hasil pengisian kuesioner, wawancara langsung dan observasi. Jumlah responden yang diambil terdiri dari 70 responden.

Pendekatan kualitatif dilakukan dengan wawancara mendalam kepada informan. Pemilihan informan dilakukan dengan menggunakan teknik purposive. Selanjutnya data kualitatif dari panduan wawancara mendalam dimasukkan pada lembar catatan harian sehingga dapat menjadi pedoman dan menganalisis data. Teknik pengumpulan data yang digunakan yaitu dengan pengambilan data dan melakukan teknik sampling. Jenis data yang digunakan dalam penelitian ini yaitu data primer dan data sekunder. Data primer berupa data kuantitatif dan kualitatif yang diperoleh dari hasil kuesioner. Data sekunder yaitu data pendukung yang didapat dari literatur baik dokumen ilmiah, jurnal, dokumen yang berhubungan dengan keadaan wilayah, demografi penduduk, karakteristik nagari dan lain-lain yang dapat digunakan sebagai penunjang penelitian.

Teknik pengolahan dan analisis data dilakukan melalui data kuantitatif dan kualitatif. Data kuantitatif diolah dengan menggunakan Microsoft Excel dan Statistical Product and Service Solution (SPSS). Analisis data kuantitatif dilakukan dengan Metode Tabel Frekuensi dan Tabulasi Silang yang disesuaikan dengan kebutuhan penelitian dan ketersedian data. Teknik pengolahan data dilakukan dengan dibuatkan klaster berdasarkan bentuk pengelolaan hutan dimana responden menjadi 
objeknya pada bentuk-bentuk pengelolaan hutan nagari. Data kualitatif berupa data primer dan sekunder.

Data kualitatif dianalisis melalui tiga tahap yaitu reduksi data, penyajian data, dan verifikasi. Pertama ialah proses reduksi data dimulai dari proses pemilihan dan penyederhanaan data hasil wawancara mendalam berupa catatan lapangan, observasi, dan studi dokumen yang direduksi dalam tulisan tematik. Tujuan dari reduksi data ini ialah untuk mempertajam, menggolongkan, mengarahkan, dan membuang data yang tidak perlu. Kedua ialah penyajian data dengan menyusun segala informasi dan data yang diperoleh menjadi serangkaian katakata yang mudah dibaca ke dalam sebuah laporan berupa kutipan atau tipologi. Verifikasi adalah langkah terakhir yang merupakan penarikan kesimpulan dari hasil yang telah diolah untuk mendukung data kuantitatif. Seluruh hasil penelitian pada akhirnya akan dituliskan dalam skripsi.

\section{HASIL DAN PEMBAHASAN}

\section{Gambaran Umum Hutan Nagari Sungai Buluh}

Pengelolaan hutan nagari Sungai Buluh dikelola secara adat dari tahun 2014, pengelolaan hutan negara diserahkan kepada nagari didasarkan kepada Surat Keputusan Gubernur Sumatera Barat Nomor: 522.4-789-2014 tentang Pemberian Hak Pengelolaan Hutan Nagari pada Kawasan Hutan Lindung seluas \pm 780 Hektar kepada Lembaga Pengelolaan Hutan Nagari Sungai Buluh, Kabupaten Padang Pariaman Provinsi Sumatera Barat. Izin pengelolaan hutan untuk dikelola oleh masyarakat nagari selama jangka waktu yang ditetapkan oleh pemerintah yaitu selama 35 tahun.

Pada kawasan hutan nagari Sungai Buluh terdapat kerjasama yang berkesinambungan antara pemerintah daerah dan para pemimpin adat untuk menentukan kegiatan pendampingan. Kegiatan pendampingan tersebut dapat berasal dari pemerintah, Lembaga Swadaya, Perguruan Tinggi atau pihak lain dalam upaya pemberdayaan masyarakat.

Untuk mengelola kawasan hutan nagari masyarakat membentuk lembaga pengelolaan hutan nagari, lembaga tersebut memiliki tugas untuk melaksanakan tata batas hak pengelolaan hutan nagari, menyusun rencana kerja, melakukan perlindungan hutan, melaksanakan rehabilitasi dan membuat rencana pengelolaan sesuai dengan arahan dari kemeterian lingkungan hidup Indonesia. Hutan nagari Sungai Buluh membentuk aturan-aturan adat yang tidak boleh dilanggar oleh masyarakat nagari. Aturan dan larangan yang diterapkan berlaku untuk semua masyarakat nagari, dengan adanya norma yang diterapkan pada kawasan hutan nagari, dinilai mampu mengurangi penebangan kayu secara ilegal dan dapat menjaga kawasan hutan dari pembalakan liar.

Pengelolaan hutan nagari Sungai Buluh yang dikelola berdasarkan kearifan lokalnya terdiri dari tiga pembagian kawasan hutan. Pembagian hutan nagari Sungai Buluh dibagi berdasarkan peruntukannya masing-masing yaitu rimbo larangan, hutan simpanan dan hutan olahan / parak. Pembagian kawasan hutan tersebut merupakan salah bentuk kearifan lokal masyarakat dalam mengelola sumberdaya hutan, bagi masyarakat Minangkabau hutan merupakan sumberdaya yang harus dijaga dan dimanfaatkan secara optimal. Pemanfaatan hutan yang dibagi berdasarkan pemanfaatan tersebut dikelola berdasarkan kepemilikan tanah ulayat kaum, artinya adalah masyarakat selain dari kaum yang memiliki tanah ulayat dilaranga terlibat dalam mengelola kawasan hutan atau memanfaatkan kawasan hutan nagari.

Pemanfaatan hutan nagari Sungai Buluh pada kawasan "rimbo larangan" memiliki aturan dan norma yang ketat, pada kawasan "rimbo larangan" masyarakat nagari tidak diizinkan untuk memanfaatkan hasil hutan kayu yang ada didalam kawasan hutan kecuali masyarakat yang tidak mampu maka diberikan izin melalui kesepakatan para "ninik mamak" yang memimpin masing-masing kaumnya, hal ini dikarenakan jika hasil kayu ditebang maka kerusakan sumberdaya air yang ada pada kawasan hutan akan berimbas kepada kebutuhan sumberdaya air dimasyarakat dan masyarakat yang diberi izin hanya diberi kesempatan untuk mengambil kayu sebanyak dua batang dan harus menggantinya dengan bibit pohon yang baru. Selain itu masyarakat percaya bahwa adanya mitos mengenai "inyiak balang" sipenjaga hutan nagari, "inyiak balang" merupakan harimau jadi-jadian yang menjaga hutan dari keserakahan manusia yang ingin mengambil hasil hutan nagari.

Pada kawasan hutan simpanan masyarakat nagari Sungai Buluh memanfaatkan kawasan tersebut sebagai hutan cadangan untuk memenuhi kebutuhan sehari-hari masyarakat jika terjadi kelangkaan pangan. Hutan simpanan pada akhirnya akan dinikmati hasilnya oleh anak kemenakan yang ada di 
nagari sebagai hutan cadangan hutan simpanan memiliki manfaat yang cukup besar seperti sebagai cadangan pangan.

Selain pengelolaan hutan simpanan sebagai hutan cadangan masyarakat nagari Sungai Buluh memanfaatkan hutan sebagai salah satu sumber perekonomian atau parak. Parak di nagari Sungai Buluh ditanami dengan tanaman-tanaman yang memiliki nilai jual bagi masyarakat. Pada kawasan "parak" masyarakat nagari dilarang mengambil hasil madu dari "lobah sialang" dengan cara menebang pohon nya hal ini dikarenakan jika pohon nya ditebang maka hasil lebah akan lari dan berpindah kepohon lain dan harus menunggu waktu yang cukup lama untuk dipanen dan dimanfaatkan kembali oleh masyarakat nagari.

\section{Gambaran Umum Hutan Nagari Paru}

Nagari Paru adalah salah satu Nagari yang memiliki kawasan Hutan yang cukup luas yang masuk ke dalam kawasan KPHL Model Sijunjung, Hutan Nagari Paru yang di kenal dengan "Rimbo Larangan Paru" berada di Kecamatan Sijunjung. Hutan nagari Paru merupakan salah satu hutan percontohan untuk pengimplementasian program REDD+ yang sekarang sedang menjadi perhatian pemerintah Indonesia maupun dunia Internasional, hal ini dibuktikan dengan adanya peraturan Nagari No. 1 tahun 2002 tentang Hutan Lindung "Rimbo Larangan Paru" pada tahun 2003 telah dibentuk kelompok Tani peduli Hutan oleh Nagari Paru dengan No. 188.47/05/Kpts-Wn-2003 tanggal 10 April 2003 tentang penetapan kelompok tani peduli hutan sebagai pengamanan hutan pada wilayah Nagari Paru. Pengelolaan hutan nagari Paru memiliki norma dan aturan yang harus dipatuhi oleh masyarakat nagari. Pada kawasan hutan nagari masyarakat memanfaatkan sumberdaya hutan sebagai pelengkap bahan dapur rumah tangga.

Hutan nagari Paru tidak boleh ditebang karena masyarakat percaya bahwa jika hutan rusak maka kehidupan yang berada disekitar kawasan nagari Paru juga akan rusak, penetapan hutan nagari di kenagarian Paru selain ditetapkan oleh kementerian dan gubernur juga ditetapkan oleh para "ninik mamak" melalui badan musyawarah nagari. Penetapan tersebut dilakukan agar tidak terjadi kesalahpahaman antara masyarakat nagari Paru dengan pemerintah terkait kebijakan pengelolaan hutan.
Pengelolaan hutan nagari Paru tidak jauh berbeda dengan pengelolaan hutan nagari Sungai Buluh. Pengelolaan hutan nagari merupan konsep dasar masyarakat kaum di Sumatera Barat dalam memanfaatkan sumberdaya hutan. Hutan di nagari dikelola dengan kearifan lokal yang berlaku sesuai kondisi masyarakat dan kondisi alam di nagari Paru. Pengelolaan hutan nagari Paru dibagi berdasarkan peruntukannya yaitu rimbo larangan, hutan simpanan dan hutan olahan/parak. Pembagian kawasan hutan tersebut sesuai dengan jumlah kaum yang ada di nagari Paru dan dikelola secara komunal oleh masyarakat nagari. Hutan nagari Paru juga dibagi berdasarkan tiga kawasan, namun pembagian kawasan hutan nagari Paru menjadi tiga kawasan dikarenakan kondisi hutan nagari pada zaman dahulu sudah mulai kelihatan rusak secara perlahan sehingga masyarakat nagari mengajukan permohonan melalui badan musyawarah nagari agar hutan dikelola oleh masyarakat nagari.

Pemanfaatan hutan nagari Paru terdiri dari tiga yaitu "rimbo larangan" sebagai kawasan yang memiliki kestabilan ekologi, hutan simpanan sebagai hutan yang dimanfaatkan oleh anak kemanakan nagari dan hutan olahan/parak sebagai ladang bagi masyarakat nagari. Pada kawasan "rimbo larangan" di nagari Paru memiliki aturan dan larangan yang memiliki sanksi yang tegas, pada kawasan "rimbo larangan" masyarakat nagari tidak diizinkan untuk memanfaatkan hasil hutan kayu yang ada didalam kawasan hutan hal ini dikarenakan rimbo larangan merupakan kawasan hutan yang harus dijaga fungsinya sebagai salah satu sumberdaya air masyarakat nagari. Sumberdaya air yang ada pada "rimbo larangan" dimanfaatkan untuk irigasi sawah masyarakat. Selain itu masyarakat Paru memiliki kepercayaan jika ada pohon yang tumbang di kawasan "rimbo larangan" tidak boleh dimanfaatkan kayunya dan dibiarkan saja. Kepercayaan ini memiliki makna "nan asalnyo dari tanah bia baliak ka tanah" artinya apa yang berasal dari tanah harus dikembalikan pada tanah, tujuan dari kepercayaan ini adalah supaya "rimbo larangan" di nagari Paru tetap terjaga keaslian nya karena pohon yang tumbang sekalipun dapat jadi pupuk bagi tanaman disekitarnya.

Pada kawasan hutan simpanan masyarakat memanfaatkan kawasan tersebut sebagai hutan cadangan untuk memenuhi kebutuhan sehari-hari masyarakat jika terjadi kelangkaan pangan persetujuan pengelolaan hutan simpanan harus berdasarkan kesepatakan para "ninik mamak" pada 
kawasn hutan simpanan hasil hutan yang dimanfaatkan hanya rotan dan paku-pakuan. Masyarakat nagari Paru mengelola hutan sebagai salah satu sumber penghasilan yaitu "Parak". Parak merupakan kawasan yang dijadikan ladang untuk berkebun pada kawasan parak ditanami tanaman seperti karet, petai dan gaharu. Parak dibuka dengan cara cukup dibersihkan saja semak belukar yang tumbuh didalamnya, parak tidak boleh dibuka dengan cara dibakar karena dapat merusak ekositem hutan pada parak masyarakat harus menanam tanaman dengan menggunakan pupuk alami dan tidak boleh menggunakan pupuk kimia.

\section{Karakteristik Responden}

Unit analisis pada penelitian ini adalah kepala rumah tangga baik ibu rumah tangga atau bapak rumah tangga yang sekaligus sebagai kepala rumah tangga. Dalam penelitian ini, jumlah responden yang diteliti sebanyak 70 responden yang terdiri dari 35 responden di Nagari Paru dan 35 responden di Nagari Sungai Buluh. Rumah tangga di Nagari Paru dan Nagari Sungai Buluh memiliki status sosial yang berbeda.

Tabel 1 Jumlah dan persentase responden menurut pekerjaan kepala rumah tangga di Nagari Sungai Buluh dan Nagari Paru

\begin{tabular}{lcccc}
\hline \multirow{2}{*}{$\begin{array}{c}\text { Pekerjaan } \\
\text { Kepala Rumah }\end{array}$ Tangga } & \multicolumn{2}{c}{$\begin{array}{c}\text { Nagari Sungai } \\
\text { Buluh }\end{array}$} & \multicolumn{2}{c}{ Nagari Paru } \\
\cline { 2 - 5 } & $\mathrm{n}$ & $\%$ & $\mathrm{n}$ & $\%$ \\
\hline Petani & 25 & 71.42 & 30 & 85.71 \\
Tukang Perabot & 2 & 5.71 & 2 & 5.71 \\
PNS & 5 & 14.28 & 2 & 5.71 \\
Guru Honorer & 3 & 8.57 & 1 & 2.85 \\
TNI/Polisi & 0 & 0 & 0 & 0 \\
\hline \multicolumn{1}{c}{ Jumlah } & 35 & 100 & 35 & 100 \\
\hline
\end{tabular}

Tabel 1 menunjukkan bahwa dari total 35 responden rumah tangga di nagari Sungai Buluh, sebanyak dua puluh lima orang atau 71.42 persen kepala rumah tangga bekerja sebagai petani, dua responden atau 5.71 persen bekerja sebagai tukang perabot, lima responden atau 14.28 persen bekerja sebagai PNS dan guru honorer sebanyak 3 responden atau 8.57 persen dan kepala ruamh tangga yang bekerja sebagai TNI/Polisi tidak ada. Berbeda dengan nagari Paru pekerjaan kepala rumah tangga lebih dominan bekerja sebagai petani yaitu sebanyak tiga puluh responden atau 85.71 persen, tukang perabot dan PNS masing-masing sebanyak dua orang atau sebesar 5.71 persen dan guru honorer sebanyak satu kepala rumah tangga atau 2.85 persen.

Usia merupakan hal yang penting bagi produktivitas seseorang dalam melakukan sesuatu usaha atau kegiatan. Berdasarkan umurnya, penduduk yang berusia 0-14 tahun merupakan penduduk yang belum produktif, penduduk yang berusia 15-64 tahun merupakan penduduk dengan usia produktif, sedangkan penduduk yang berusia 65 tahun ke atas merupakan penduduk dengan usia kurang produktif (Kusumowidho 2000). Usia responden dikelompokkan menjadi tujuh kelompok umur yakni 15-24 tahun, 25-34 tahun, 35-44 tahun, 45-54 tahun, 55-64 tahun, 65-75 tahun dan lebih dari 75 tahun. Berikut data usia responden disajikan pada tabel 2.

Tabel 2 Jumlah dan persentase responden menurut kelompok umur di Nagari Sungai Buluh dan Nagari Paru tahun 2017

\begin{tabular}{ccccc}
\hline \multirow{2}{*}{ Umur } & \multicolumn{2}{c}{ Sungai Buluh } & \multicolumn{2}{c}{ Nagari Paru } \\
\cline { 2 - 5 } & $\mathrm{n}$ & $\%$ & $\mathrm{n}$ & $\%$ \\
\hline $15-24$ & 3 & 8,57 & 10 & 28,57 \\
$25-34$ & 14 & 40 & 0 & 0 \\
$35-44$ & 18 & 51,5 & 0 & 0 \\
$45-54$ & 0 & 0 & 20 & 57,14 \\
$55-64$ & 0 & 0 & 5 & 14,28 \\
$65-75$ & 0 & 0 & 0 & 0 \\
$>75$ & 0 & 0 & 1 & 2,85 \\
\hline Jumlah & 35 & 100 & 35 & 100 \\
\hline
\end{tabular}

Tabel 2 menunjukkan bahwa kelompok umur responden mayoritas masuk ke dalam usia produktif yakni 15-64 tahun. Jumlah kelompok umur terbesar yakni 35-44 tahun sebesar 51.5\% atau 18 responden di Nagari Sungai Buluh dan kelompok umur 45-54 tahun sebesar $57.14 \%$ atau 20 responden di Nagari Paru. Dari 70 responden penelitian, terdapat 1 responden atau 2.86 persen yang berusia diatas 75 tahun tepatnya berusia 73 tahun dan hingga kini tetap aktif melakukan kegiatan memanen getah dan mencari nafkah. Tingkat pendidikan responden diukur dengan jenjang pendidikan formal atau nonformal terakhir yang telah ditempuh oleh responden. Terdapat lima jenjang pendidikan responden di Nagari Sungai Buluh dan Nagari Paru yakni tidak tamat sekolah dasar, tamat sekolah dasar (SD)/sederajat, tamat sekolah menengah pertama (SMP)/sederajat, tamat sekolah menengah atas (SMA)/sederajat dan perguruan tinggi. Data tingkat pendidikan responden disajikan pada Tabel 3. 
Tabel 3 Jumlah dan persentase responden berdasarkan tingkat pendidikan di Nagari Sungai Buluh dan Paru

\begin{tabular}{lcccc}
\hline \multicolumn{1}{c}{$\begin{array}{c}\text { Tingkat } \\
\text { Pendidikan }\end{array}$} & \multicolumn{2}{c}{$\begin{array}{c}\text { Nagari Sungai } \\
\text { Buluh }\end{array}$} & \multicolumn{2}{c}{ Nagari Paru } \\
\cline { 2 - 5 } & $\mathrm{n}$ & $\%$ & $\mathrm{n}$ & $\%$ \\
\hline $\begin{array}{l}\text { Tidak Tamat } \\
\text { SD }\end{array}$ & 0 & 0 & 0 & 0 \\
$\begin{array}{l}\text { Tamat SD/ } \\
\begin{array}{l}\text { Sederajat } \\
\text { Tamat SMP/ }\end{array}\end{array}$ & 7 & 20 & 0 & 0 \\
$\begin{array}{l}\text { Sederajat } \\
\text { Tamat SMA/ }\end{array}$ & 19 & 25.71 & 4 & 11.42 \\
$\begin{array}{l}\text { Sederajat } \\
\text { Perguruan } \\
\text { Tinggi }\end{array}$ & 0 & 0 & 5 & 14.28 \\
\hline \multicolumn{1}{c}{ Jumlah } & 35 & 100 & 35 & 100 \\
\hline
\end{tabular}

Tabel 3 menunjukkan bahwa baik di Nagari Sungai Buluh dan Nagari Paru mayoritas responden berpendidikan terakhir SMA sederajat dengan persentase 54.38 persen atau 19 responden di Nagari Paru dan 74.28 persen atau 26 responden di Nagari Paru. Sebesar 14.28 persen atau hanya lima orang di Nagari Paru berpendidikan terakhir tamat perguruan tinggi. Beberapa faktor masih rendahnya tingkat pendidikan di dua lokasi karena keterbatasan akses pendidikan, baik dari segi lokasi yang jauh maupun biaya yang mahal untuk bisa melanjutkan ke jenjang yang lebih tinggi. Pendapatan rumah tangga dihitung dari penghasilan dalam satu bulan yang didapatkan oleh kepala rumah tangga atau anggota rumah tangga yang bekerja.

Tabel 4 Jumlah dan persentase responden berdasarkan pendapatan rata-rata per bulan di Nagari Sungai Buluh dan Nagari Paru tahun 2017

\begin{tabular}{ccccc}
\hline $\begin{array}{c}\text { Pendapatan Rata- } \\
\text { Rata per Bulan } \\
\text { (rupiah) }\end{array}$ & \multicolumn{2}{c}{$\begin{array}{c}\text { Nagari Sungai } \\
\text { Buluh }\end{array}$} & \multicolumn{2}{c}{ Nagari Paru } \\
\cline { 2 - 5 } & $\mathrm{n}$ & $\%$ & $\mathrm{n}$ & $\%$ \\
\hline Rendah & 23 & 65 & 26 & 74.2 \\
Sedang & 2 & 5.7 & 3 & 8.57 \\
Tinggi & 10 & 28 & 6 & 17.1 \\
\hline Jumlah & 35 & 100 & 35 & 100 \\
\hline
\end{tabular}

Tabel 4 menunjukkan bahwa mayoritas responden di Nagari Sungai Buluh atau 65.71 persen berada pada golongan pendapatan rumah tangga yang rendah dan mayoritas responden di Nagari Paru atau 74.28 persen berada pada golongan pendapatan rumah tangga yang rendah. Responden dengan golongan pendapatan rumah tangga yang tinggi di Nagari
Sungai Buluh lebih besar daripada responden di Nagari Paru dengan masing-masing 28.57 persen dan 17.14 persen. Beberapa hal yang menyebabkan masih rendahnya pendapatan rumah tangga responden di Nagari Sungai Buluh dan Paru adalah kurangnya lapangan pekerjaan dan sulitnya akses jalan untuk menuju ke pusat kabupaten dan pasar.

\section{Peran Praktik Kearifan Lokal dalam Keberlanjutan Hutan Nagari}

Kearifan lokal merupakan faktor penting dalam mengelola sumberdaya hutan, jika kearifan lokal diabaikan oleh masyarakat dalam mengelola sumberdaya alam maka kerusakan akibat eksploitasi yang dilakukan oleh manusia akan terus meningkat dan pada akhirnya akan terjadi krisis sumberdaya alam. Krisis sumberdaya alam dapat terjadi jika tidak ada peraturan yang mengontrol pengelolaan sumberdaya alam, peraturan-peraturan tersebut lebih dikenal dengan istilah norma yang terdapat pada kearifan lokal. Menurut (Keraf, 2010) terdapat sekitar $80 \%$ penduduk bumi yang memiliki kearifan lokal, masih banyaknya praktik kearifan yang lokal yang dilakukan oleh masyarakat dapat dijadikan sebagai acuan untuk bertahan hidup lebih lama dalam menjalani kehidupan modern.

\section{Peran Kearifan Lokal dalam Keberlanjutan Hutan Nagari Sungai Buluh}

Pengelolaan hutan nagari berdasarkan tiga bentuk pengelolaan hutan merupakan salah satu bentuk kearifan lokal masyarakat dalam menjaga kelestarian lingkungan, pada bab ini akan dibahas praktik pengelolaan rimbo larangan dan hubungan nya dengan keberlanjutan sumberdaya alam. Keberlanjutan sumberdaya dikelompokan menjadi tiga kelompok yaitu ekologi,sosial budaya dan ekonomi. Pada pengelolaan rimbo larangan kelestarian hutan dan keberlanjutan ekologi merupakan tujuan utama dari praktik pengelolaan hutan nagari. Pengelolaan rimbo larangan yang baik akan menciptakan keberlanjutan ekologi dan disekitar lingkungan kawasan.

Tabel 5 menunjukkan bahwa terdapat hubungan antara praktik kearifan lokal di kenagarian Sungai Buluh dengan keberlanjutan sumberdaya alam dihasilkan nilai koefisien korelasi sebesar 596** yang menunjukkan bahwa terdapat hubungan antara praktik pengelolaan hutan dengan keberlanjutan sumberdaya alam. Tanda bintang $(* *)$ menunjukkan bahwa korelasi signifikan pada nilai signifikansi .000. Angka koefisien korelasi tersebut bernilai 
positif yakni sebesar 596 sehingga hubungan kedua variabel tersebut bersifat searah. Maka dari itu dapat diartikan bahwa semakin tinggi nilai praktik pengelolaan hutan maka nilai keberlanjutan sumberdaya alam akan semakin tinggi.

Tabel 5 Hasil uji korelasi rank spearman antara praktik kearifan lokal dan keberlanjutan hutan nagari Sungai Buluh

\begin{tabular}{cll}
\hline Variable dan dimensi & \multicolumn{2}{c}{$\begin{array}{c}\text { Keberlanjutan Hutan } \\
\text { Nagari }\end{array}$} \\
\cline { 2 - 3 } & $\mathrm{R}$ & $\mathrm{p}$ \\
\hline Praktik Kearifan Lokal & $596^{* *}$ & 000 \\
1. Rimbo larangan & 141 & 420 \\
2. Hutan simpanan & $770^{* *}$ & 000 \\
3. Parak & $614^{* *}$ & 000 \\
\hline
\end{tabular}

\section{Peran Kearifan Lokal dalam Keberlanjutan Hutan Nagari Paru}

Pengelolaan hutan nagari di Sumatera Barat pada umumnya memiliki pembagian yang dibagi sesuai dengan fungsinya seperti rimbo larangan, hutan simpanan dan parak. Pembagian kawasan hutan tersebut bertujuan untuk menunjang tingkat keberlanjutan sumberdaya alam. Keberlanjutan sumberdaya alam dikelompokan menjadi tiga kelompok yaitu ekologi,sosial budaya dan ekonomi. Pengelolaan hutan nagari yang baik akan mewujudkan keberlanjutan sumberdaya alam dan dapat meningkatkan taraf hidup masyarakat nagari. Peran praktik kearifan lokal merupakan faktor penting dalam mewujudkan keberlanjutan hutan nagari Paru. Berdasarkan hasil uji korelasi rank spearman antara praktik kearifan lokal dengan keberlanjutan keberlanjutan hutan nagari, disajikan data sebagai berikut.

Tabel 6 Hasil uji korelasi rank spearman antara praktik kearifan lokal dan Keberlanjutan hutan Nagari Paru

\begin{tabular}{|c|c|c|}
\hline \multirow[t]{2}{*}{ Variable dan dimensi } & \multicolumn{2}{|c|}{$\begin{array}{c}\text { Keberlanjutan Hutan } \\
\text { Nagari }\end{array}$} \\
\hline & $\mathrm{R}$ & $\mathrm{p}$ \\
\hline Praktik Kearifan Lokal & 265 & 124 \\
\hline 1. Rimbo larangan & -225 & 194 \\
\hline 2. Hutan simpanan & 091 & 604 \\
\hline 3. Parak & 252 & 145 \\
\hline
\end{tabular}

Tabel 6 menunjukkan bahwa tidak terdapat hubungan antara praktik kearifan lokal di kenagarian Paru dengan keberlanjutan sumberdaya alam dihasilkan nilai koefisien korelasi sebesar 265 yang menunjukkan bahwa tidak terdapat hubungan antara praktik pengelolaan hutan dengan keberlanjutan sumberdaya alam dengan nilai signifikansi sebesar 124 dibawal 0. Maka dari itu dapat diartikan bahwa praktik pengelolaan hutan tidak memiliki keberlanjutan terhadap sumberdaya alam.

Selain itu, Tabel 6 menunjukkan bahwa nilai alfa (p) antara praktik pengelolaan hutan dengan keberlanjutan sumberdaya alam yakni sebesar 124 . Nilai alfa (p) yang lebih besar dari 0.01 mengartikan bahwa tidak terdapat hubungan yang signifikan antara praktik pengelolaan hutan dengan keberlanjutan sumberdaya alam. Berdasarkan penjabaran tersebut, maka hipotesis pada penelitian ini tidak dapat diterima yakni tidak terdapat hubungan positif antara praktik pengelolaan hutan dengan keberlanjutan sumberdaya alam.

\section{SIMPULAN DAN SARAN}

\section{Simpulan}

Berdasarkan hasil penjelasan pada bab sebelumnya, maka dapat disimpulkan bahwa secara umum praktik pengelolaan hutan responden di nagari Sungai Buluh lebih tinggi dibandingkan nagari Paru. Artinya responden nagari Sungai Buluh masih menerapkan peraturan yang ada dan memanfaatkan hasil hutan dengan cara yang baik dan didukung oleh akses masyarakat nagari Sungai Buluh yang tidak jauh dari pusat-pusat pemerintahan. Mengukur praktik pengelolaan hutan pada penelitian ini berdasarkan kepada bentuk praktik pengelolaan hutan di tiga kawasan yaitu rimbo larangan, hutan simpanan dan parak. Selain itu, nagari Sungai Buluh masih menjaga tradisi dan memanfaatkan sumberdaya alam dengan baik sehingga keberlanjutan sumberdaya alam masih dapat dirasakan oleh masyarakat. Pada pengelolaan hutan nagari Sungai Buluh hanya rimbo larangan yang memiliki hubungan dengan keberlanjutan hutan nagari yang tidak signifikan sedangkan hutan simpanan dan parak memiliki hubungan yang kuat dengan keberlanjutan hutan nagari. Keberlanjutan hutan nagari diukur berdasarkan tingkat keberlanjutan sumberdaya alam yang terdiri dari keberlanjutan ekologi, sosialbudaya dan ekonomi. Berdasarkan hasil olah data pada masing-masing pengelolaan hutan seperti rimbo larangan, hutan simpanan dan parak pada nagari Sungai Buluh cenderung memiliki keberlanjutan hutan yang rendah baik itu keberlanjutan ekologi, sosial-budaya ataupun keberlanjutan ekonomi.

\section{Saran}


Penelitian yang membandingkan praktik kearifan lokal dalam pengelolaan hutan nagari/adat terhadap keberlanjutan sumberdaya alam masih belum banyak yang meneliti sehingga penulis menyadari bahwa penelitian ini masih banyak sekali kekurangan yang perlu diperbaiki untuk ke depannya. Beberapa saran penulis untuk perbaikan selanjutnya bagi yang ingin melanjutkan atau meneliti kembali perbandingan keberlanjutan sumberdaya alam antara pengelolaan hutan adat adalah (1) Bagi pemerintah, perlu didukung masyarakat nagari dalam mempertahankan sumberdaya alam dan sumberdaya hutan; (2) Sebaiknya penelitian selanjutnya melibatkan mahasiswa ilmu budaya dan kehutanan agar dapat juga melihat kearifan lokal masyarakat sisi ilmu budaya dan kehutanan.

\section{DAFTAR PUSTAKA}

Abdurrahman. 2003. Pembangunan Berkelanjutan Dalam Mengelola Sumber Daya Alam Indonesia. Prosiding. [Internet]. [Diunduh pada tanggal 21 Februari 2017]. Seminar_Pembangunan Nasional. Dapat diunduh dariberkelanjutan pdf.

Arafah N. Darusman D. Suhartijo D. Sundawati L. 2011. Kaindea: Dinamika Pengelolaan Hutan Adat di Pulau Kecil (Studi Kasus: Pulau Wangi-Wangi Kabupaten Wakatobi).Jurnal[Internet]. [Diunduh pada tanggal 21 Februari 2017]. Ilmu Kehutanan. Vol. 5. No.1. Dapat diunduh dari:http://jurnal.ugm.ac.id/jikfkt/article/view/58 $\underline{0}$

Astid 2002. Pengaruh Agroforestry Terhadap Kehidupan Sosial Ekonomi Dan Sikap Petani Agroforesty. Dapat diunduh dari https://digilib.uns.ac.id/...=/Pengaruhagroforestry-terhadap-

Fauzi, Hamdani. 2012. Pembangunan Hutan Berbasis Kehutanan Sosial. Karya Putra Darwati. Bandung.

Firmansyah. 2007. Nagari Dan Pengelolaan Hutan (Studi Kasus Nagari Kambang, Guguak Malalo dan Kambang Provinsi Sumatera Barat). [Internet]. Buku [Diunduh pada tanggal 21 Februari 2017] Dapat diunduh dari.https://www.academia.edu/30923534/Potret _Pengelolaan_Hutan_di_Nagari

Idris N. 2012. Kedudukan Perempuan dan Aktualisasi Politik dalam Masyarakat Matrilinial Minangkabau. Jurnal. [Internet]. [Diunduh pada tanggal 10 Juni 2017]. Jurnal Masyarakat, Kebudayaan dan Politik. Vol. 25. No. 2. Diunduh.

http://web.unair.ac.id/admin/file/f_32373_23.pd $\underline{f}$
Iswantoro. 2012. Eksistensi Hak Ulayat Masyarakat Hukum Adat Dalam Hukum Agraria Nasional.Jurnal. [internet]. [diunduh pada 11 Oktober 2017].Vol 10. No 1. Februari 2012. diunduh dari jurnal.Uinsuska.ac.id/jurnal/index.php/

Karisma BM. 2010. Studi Pemanfaatan Sumberdaya Hutan Oleh Masyarakat Desa Sekitar Hutan Dan Tata Kelolanya. [Skripsi].Bogor. (ID): Institut Pertanian Bogor. [Internet]. Dapat diunduh dari: http://repository.ipb.ac.id/handle/123456789/63 478

Kusumowidho, S. 2000. Dasar-dasar demografi. Jakarta (ID): Lembaga Demografi Fakultas Ekonomi Universitas Indonesia

Murtijo. 2005. Antropologi Kehutanan. Banten: Wana Aksara

Rahayu, E., A. Amir, dan Hamidin, 2013. Petatah Petitih Masyarakat Minangkabau Di Nagari Kota Baru Kecamatan Kubung Kabupaten Solok. Jurnal. Padang (ID) Universitas Negeri Padang [internet]. [diunduh tanggal 21 Februari 2016]. Dapat diunduh di http://ejournal.unp.ac.id/index.php/pbs/article/ view/1285

Ruchyat. 2003. Pengembangan Kawasan Agropolitan Dalam Rangka Pengembangan Wilayah Berbasis Rencana Tata Ruang Wilayah Nasional (RTRWN). Diakses pada tanggal 30 Juni 2017

Senoaji G. 2004. Pemanfaatan Hutan dan Lingkungan oleh masyarakat Baduy di Banten Selatan. [Internet]. [Diunduh pada tanggal 28 Januari 2016]. Dapat diunduh dari: http://jpeces.ugm.ac.id/ojs/index.php/JML/arti cle/viewfile/361/283

Singarimbun M, Effendi S. 2006. Metode Penelitian Survai. Jakarta [ID]: LP3ES.

Suyanto. 2009. Beberapa Ancaman Terhadap Kawasan Hutan Lindung di Kabupaten Tanah Laut Kalimantan Selatan. Jurnal. [Internet]. [Diunduh pada tanggal 8 Maret 2017]. Jurnal Hutan Tropis Borneo Volume 10

Warman. 2014. Pola Hubungan Hukum Dalam Pemanfaatan Tanah Ulayat Di Sumatera Barat.Jurnal. [internet]. [diunduh pada 11 Oktober 2017]. Vol 26. No 3. Oktober 2014. diunduh dari jurnal.mimbar hukum.ac.id/jurnal/index.php/

Yamani M. 2011. Strategi Perlindungan Hutan Berbasis Hukum Lokal Di Enam Komunitas-Komunitas Adat Daerah Bengkulu. Jurnal. [Internet]. [Diunduh pada tanggal 16 Januari 2017]. Hukum. Vol. 18. No. 2.Diunduh darihttp://undana.ac.id/jsmallfibtop/JURNAL/ HUKUM/HUKUM\%202011/10\%20M.\%20Y amani.pdf 